postoperative day, and it is unlikely that this would explain the marked sex difference. It is highly unlikely that over $60 \%$ of apparently normal women had latent urinary tract infection, but perhaps the changes we have observed are in some way related to the unknown cause underlying the increased susceptibility of the female to urinary tract infection.

\section{Summary}

Semi-quantitative urinary white cell counts were performed in 198 patients before and after surgery. A significant rise in white cell excretion rates was found in $61 \%$ of the females but in only $11 \%$ of the males. The results were confirmed in a further group of patients by means of fully quantitative cell counts, and bacterial counting showed that this pyuria was often associated with significant bacteriuria. The possible significance of these findings is discussed.

\section{REFERENCES}

Addis, T. (1926). 7. clin. Invest., 2, 409.

Elden, C. A., and Cooney, J. W. (1935). Ibid., 14, 889.

Goldring, W. (1931). Ibid., 10, 355.

Houghton, B. J., and Pears, M. A. (1957). Brit. med. F., 1, 622. Hutt, M. S. R., Chalmers, J. A., MacDonald, J. S., and de Wardener,

Kennedy, W. P. U., Ormonde, N. W. H., and Murdoch, J. McC. (1964). Brit. 7. Urol., 36, 354.

Lancet, 1961, 2, 1077.

Lindsay, R. M., Linton, A. L., and Longland, C. J. (1965). Lancet, 1,978 .

McGeachie, J., and Kennedy, A. C. (1963). F. clin. Path., 16, 32. Prescott, L. F. (1965). Lancet, 2, 91.

- (1966). Clin. Sci., 31, 425.

and Brodie, D. E. (1964). Lancet, 2, 940.

Roberts, A. M. (1935). ‡. clin. Invest., 14, 31.

Rofe, P. (1955). F. clin. Path., 8, 25.

\title{
Use of Diazepam in Treatment of Severe Convulsive Status Epilepticus
}

\author{
MAURICE J. PARSONAGE,* M.B., B.SC., F.R.C.P., D.C.H. ; JOHN W. NORRIS, † M.B., M.R.c.P.
}

Brit. med. F., 1967, 3, 85-88

During the past three years diazepam (Valium) has been used extensively, both in Europe and in the U.S.A., chiefly as a tranquillizing agent but also as an anticonvulsant (Gross and Kaltenbäck, 1963 ; Goldstein, 1963 ; Trolle, 1965). Until recently there have been comparatively few published accounts of its use in the treatment of status epilepticus. One of the earliest was that of Naquet et al. (1965), and others were by Gastaut et al. (1965), Iborra (1965), Piqué and Henking (1965), Revol et al. (1965), Bamberger and Matthes (1966), and Lombroso (1966).

In common with chlordiazepoxide (Librium) and nitrazepam (Mogadon), diazepam is a member of the benzodiazepine group of drugs. It has tranquillizing, muscle relaxant, and anticonvulsant actions. In experimental animals its depressant action has been found to act mainly on structures in the limbic system, including the hippocampus, amygdala, and reticular formation (Randall et al., 1961 ; Morillo, 1962 ; Hernández-Peón et al., 1964 ; Schallek et al., 1964 ; Schallek and Kuehn, 1965). It has also been shown that seizures arising in the amygdala in rats can be prevented by the prior administration of this drug (Eidelberg et al., 1965). The literature relative to this subject has been extensively reviewed by Boyer (1966).

- Consultant Neurologist, General Infirmary at Leeds, Leeds 1.

t Registrar, Neurological Department, General Infirmary at Leeds,
We report here the use of diazepam in the treatment of nine severe cases of convulsive status epilepticus.

\section{Material and Methods}

There were four males and five females, whose ages ranged from 11 to 53 years (Table I). In practically all cases the epilepsy was of long standing and probably associated with gross brain damage. In at least six of the nine patients there was a probable source of seizure discharge in one or other frontal lobe, and in several instances there had been previous episodes of convulsive status epilepticus.

After admission to hospital all patients were at first given diazepam in 10-mg. doses ( 1 ampoule), either intravenously or intramuscularly as required. When it became apparent that the drug had only a transient action it was given as an intravenous infusion, initially in a dosage of $100 \mathrm{mg}$. in 1 litre of physiological saline. Latterly, intravenous infusions of $100 \mathrm{mg}$. of the drug in $500 \mathrm{ml}$. of saline were given.

All patients had the usual nursing care, with particular attention to respiratory function and to fluid and electrolyte balance. Whenever it was thought necessary tracheostomy and controlled respiration were employed. Tests for liver function were carried out in Cases 5-9. In most of the patients E.E.G. studies had previously been carried out with resulting location

TABLE I

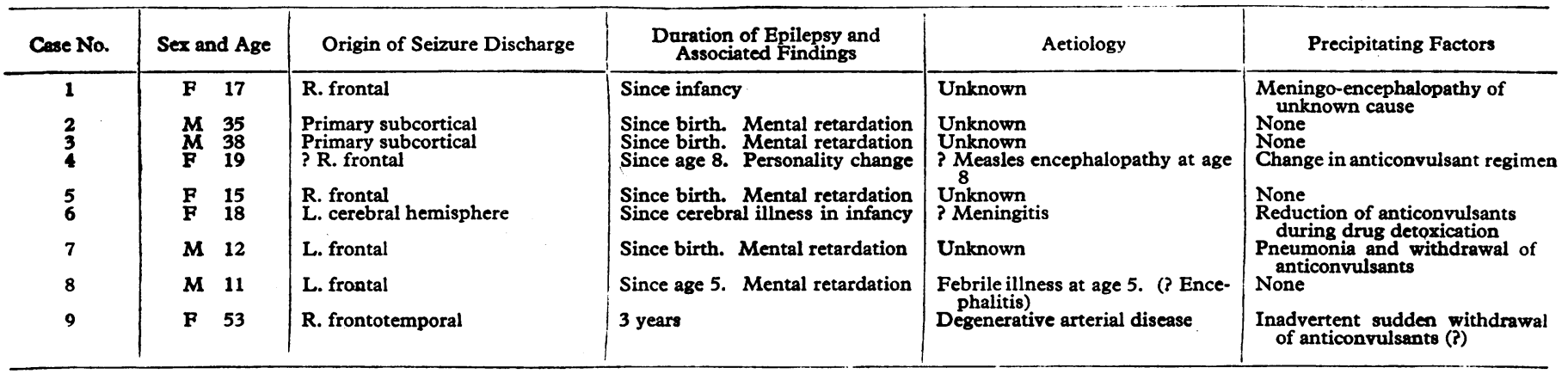


of sources of seizure discharge, but further recordings were performed as often as possible during treatment of the status epilepticus.

\section{Results}

The results are summarized in Table II. Immediate control of seizures was obtained in seven of the nine patients. In most of these the effect of diazepam was very rapid, being evident within 10-20 seconds of the beginning of the injection (see Illustration). In Cases 1 and 6 the control was not

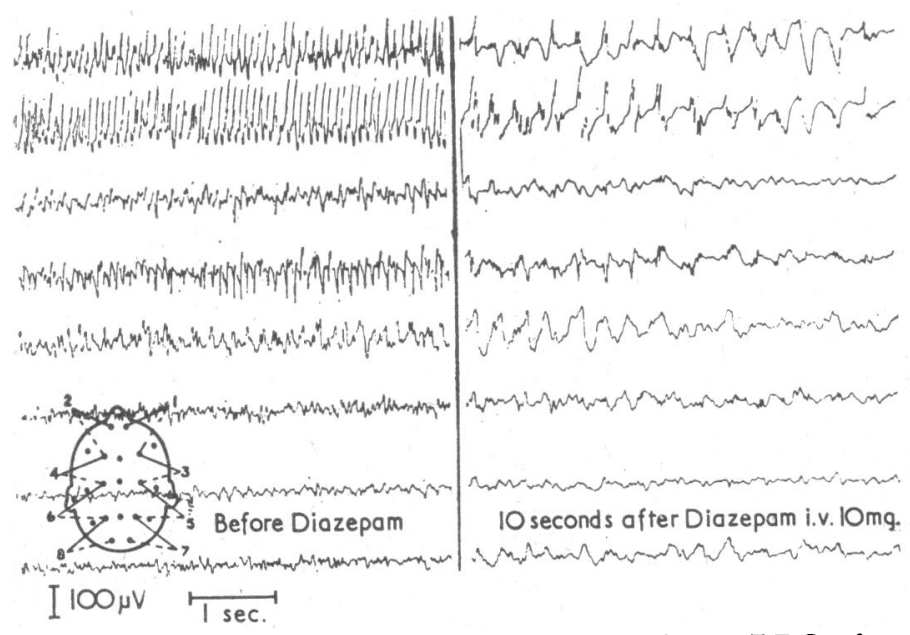

Showing the rapid interruption of seizure discharge in the E.E.G. after the intravenous administration of diazepam (Case 9).

enduring, and it was deemed advisable to resort to the use of other methods of treatment (intravenous paraldehyde, etc.).

In Case 2 treatment with diazepam was abandoned at an early stage because of initial uncertainty concerning the effects of giving the drug in high dosage. For the same reason a similar policy was adopted in Case 3 , and the seizures were eventually suppressed only with great difficulty with the aid of curarization and controlled respiration, together with the combined administration of phenobarbitone and phenytoin in high dosage. This patient was subsequently found to be severely demented.

In Cases 4 and 8 complete control of seizures was obtained after giving $10 \mathrm{mg}$. of diazepam intramuscularly. Thereafter it was given as an intravenous infusion over a period of three days while the patients were in the intensive care unit. When the seizures recurred the following day they were easily controlled with paraldehyde.

Case 7 was remarkable for the fact that control of seizures was not obtained even after the administration of $190 \mathrm{mg}$. of diazepam. The patient, a backward boy aged 12, remained in a comatose state and eventually died at the end of five weeks, presumably as a result of severe brain damage. His seizures had continued almost uninterrupted for nearly three weeks, despite curarization and controlled respiration and finally the institution of hypothermia.

In Case 9, after the intravenous administration of only $17.5 \mathrm{mg}$. of diazepam, the blood pressure fell to $70 / 50$ from a level on admission of $105 / 70$. In the belief that this might be due to diazepam, the drug was discontinued and intravenous paraldehyde given. However, as the seizures remained uncontrolled and the blood pressure had become stabilized at a level of $90 / 50$, a further $131.5 \mathrm{mg}$. of diazepam was given as an intravenous infusion in conjunction with controlled respiration. Though control of seizures was soon obtained in this way, without any further fall in blood pressure, the patient remained in a comatose state and died two days later. At necropsy an infarction of the left cerebral hemisphere was found, adjudged to be some four to five days old. It was confined to the cortical territory of the middle cerebral artery, two branches of which were found to be occluded by fibrin clot. A similar clot was attached to the intima on the dorsal wall of the abdominal aorta. In the inferomedial portion of the right temporal lobe there was gliosis of the white matter adjacent to the amygdaloid nucleus and satellitosis of cortical neurones in the deeper laminae. In this area many small arteries showed collagenous change, and similar changes were found in the corresponding area in the left temporal lobe but without any associated gliosis. There was no evidence of hypoxic damage or incisural sclerosis in either temporal lobe.

It seems likely that the degenerative vascular changes seen in the right temporal lobe in this fatal case were related to the epilepsy, particularly since they were associated in life with a local slow wave and sharp wave abnormality in the E.E.G., indicating local neuronal hyperexcitability. In view of the estimated age of the left cerebral infarction it appeared very probable that it had occurred before diazepam therapy was begun, though its relation to the onset of the status epilepticus remains problematical. Furthermore, it also seems very likely that the blood pressure had already begun to fall before treatment was started, since this patient is known to have had a blood pressure of at least $150 / 90$ in the past.

TABLE II.-Summary of Results

\begin{tabular}{|c|c|c|c|c|c|c|c|c|}
\hline \multirow[b]{2}{*}{$\begin{array}{l}\text { Case } \\
\text { No. }\end{array}$} & \multirow[b]{2}{*}{ Previous Treatment } & \multicolumn{4}{|c|}{ Treatment with Diazepam } & \multirow[b]{2}{*}{ Supplementary } & \multirow{2}{*}{$\begin{array}{c}\text { Total } \\
\text { Duration of } \\
\text { Status (days) }\end{array}$} & \multirow[b]{2}{*}{ Final Result } \\
\hline & & $\begin{array}{c}\text { Day } \\
\text { Treatment } \\
\text { Begun }\end{array}$ & $\begin{array}{c}\text { Maximum } \\
\text { Dose in } \\
24 \text { hours } \\
\end{array}$ & $\begin{array}{c}\text { Total } \\
\text { Amount } \\
\text { Given }\end{array}$ & Effect & & & \\
\hline 1 & $\overline{\text { Paraldehyde on 1st day }}$ & 2nd & $30 \mathrm{mg}$. & $\begin{array}{c}30 \text { mg. over } \\
24 \text { hours }\end{array}$ & Temporary control & Paraldehyde & 6 & $\begin{array}{l}\text { Ultimate control. } \\
\text { Residual mild left } \\
\text { hemiparesis }\end{array}$ \\
\hline 2 & $\begin{array}{l}\text { Paraldehyde (i.m.) and } \\
\text { phenytoin (i.v.) for } 3 \\
\text { days }\end{array}$ & 3 rd & $30 "$ & $\begin{array}{l}30 \text { mg. over } \\
24 \text { hours }\end{array}$ & Temporary control & $\begin{array}{l}\text { Controlled respiration. } \\
\text { Thiopentone (i.v.) }\end{array}$ & 3 & $\begin{array}{l}\text { nemiparesis } \\
\text { No change }\end{array}$ \\
\hline 3 & $\begin{array}{l}\text { Paraldehyde } 10 \mathrm{ml} . \\
\text { (i.m.) on } 1 \mathrm{st} \text { day }\end{array}$ & 1st & $40 "$ & $\begin{array}{l}70 \text { mg. over } \\
2 \text { days }\end{array}$ & Unsatisfactory control & $\begin{array}{l}\text { Controlled respiration. } \\
\text { Curarization. Pheno- } \\
\text { barbitone and } \\
\text { phenytoin }\end{array}$ & 8 & Severe dementia \\
\hline 4 & None & 1 st & 150, & $\begin{array}{l}335 \text { mg over } \\
7 \text { days }\end{array}$ & $\begin{array}{l}\text { Temporary control } \\
\text { i.m. but complete } \\
\text { when given i.v. }\end{array}$ & $\begin{array}{l}\text { phen } \\
\text { None }\end{array}$ & 7 & No change \\
\hline 5 & None & 1 st & 160, & $\begin{array}{l}170 \mathrm{mg} . \text { over } \\
3 \text { days }\end{array}$ & $\begin{array}{l}\text { when given i.v. } \\
\text { Satisfactory control }\end{array}$ & Paraldehyde & 17 & $\begin{array}{l}\text { Persistent elevation of } \\
\text { serum alkaline } \\
\text { phosphatase level }\end{array}$ \\
\hline 6 & None & $18 t$ & $200 \%$ & $\begin{array}{l}900 \text { mg. } \\
\text { (approx.) } \\
\text { over } 7 \text { days }\end{array}$ & Temporary control & $\begin{array}{l}\text { Controlled respiration. } \\
\text { Intracarotid amylo- } \\
\text { barbitone }\end{array}$ & $4-5$ & No change \\
\hline 7 & $\begin{array}{l}\text { Paraldehyde (i.m.) on } \\
\text { 1st day }\end{array}$ & 2nd & 140, & $\begin{array}{l}190 \mathrm{mg} \text {. over } \\
3 \text { days }\end{array}$ & None & $\begin{array}{l}\text { Controlled respiration. } \\
\text { Paraldehyde. Hypo- } \\
\text { thermia }\end{array}$ & 20 & $\begin{array}{l}\text { Severe brain damage. } \\
\text { Died }\end{array}$ \\
\hline 8 & None & 1st & $\begin{array}{l}150, \\
\text { (approx.) }\end{array}$ & $\begin{array}{l}350 \text { mg. over } \\
7 \text { days }\end{array}$ & Complete control & None & $2-3$ & No change \\
\hline 9 & None & 1st & $\begin{array}{l}\text { (approx.) } \\
149 \mathrm{mg} \text {. }\end{array}$ & $\begin{array}{l}169 \text { mg. over } \\
2 \text { days }\end{array}$ & Satisfactory control & $\begin{array}{l}\text { Controlled respiration. } \\
\text { Paraldehyde }\end{array}$ & 3 & $\begin{array}{l}\text { Hypotension. Cerebral } \\
\text { infarction. Died }\end{array}$ \\
\hline
\end{tabular}




\section{Side-effects}

A hypnotic effect was evident to some degree in most cases when the dosage of diazepam exceeded $10 \mathrm{mg}$. intravenously. In higher dosage semicoma usually supervened, but this was always transient. There were, however, no abnormal mental changes as described by Femi-Pearse (1966).

A tendency to the development of tolerance became evident when continuous intravenous infusions of diazepam were employed in dosages ranging from 300 to $500 \mathrm{mg}$. spread over a period of two to three days. This was particularly striking in Case 6, in which the drug appeared to lose its effect on the seizures, and this could not be restored when intermittent intravenous injections were given subsequently.

There were no cases in which respiratory suppression occurred as a result of the administration of diazepam. No abnormalities of the peripheral blood picture or of renal function were encountered.

Evidence of abnormal liver function was found in three patients (Cases 5, 8, and 9). In the first of these there had been an illness six months previously characterized by fever, lymphadenopathy, and hepatosplenomegaly which was thought to be due to a toxic reaction to methoin therapy. After the administration of just over $100 \mathrm{mg}$. of diazepam there was found to be a rise in the serum aspartate aminotransferase level to 62 units, while that of the serum alkaline phosphatase had risen to 19.6 K.A. units. The serum alanine aminotransferase level remained normal. The serum aspartate aminotransferase level returned to normal within a week, whereas the alkaline phosphatase level has remained raised (30-40 K.A. units). In Case 8 a rise of the serum aspartate aminotransferase level to 64 units was found after two days' treatment with approximately $250 \mathrm{mg}$. of diazepam, but this had returned to normal at the end of a week. In Case 9 the serum aspartate aminotransferase level had risen to 68 units on the second day of treatment, but the patient did not survive long enough for any further estimations to be made.

In no case was there any evidence of tissue necrosis at the site of injection.

\section{Discussion}

In all our patients except one (Case 7) the immediate suppressant effect of diazepam on convulsive seizures was clearly evident. This was seen, however, only when the drug was given intravenously, and we were not able to confirm the observation of Naquet et al. (1965) that status epilepticus was terminated within minutes of the intramuscular injection of diazepam. It is noteworthy that Piqué and Henking (1965) used the intravenous route in all their cases, whereas Iborra (1965) and Gastaut et al. (1965) used both the intravenous and the intramuscular routes. However, since the two routes were often used in the same patient it is difficult to conclude which was the more effective.

In our first three patients diazepam was given in relatively small doses intermittently lest dangerous side-effects should occur, and also after other treatment had proved to be ineffective ; even so, the effect of diazepam was appreciable, and satisfactory control of seizures might have been achieved if larger doses had been given. In the remaining six patients treatment with diazepam was begun earlier and much larger doses were given by continuous infusion. In four of these good control of seizures was obtained, though in Case 6 it was only temporary and other measures had to be used.

Case 7 was remarkable for the fact that neither the administration of diazepam nor any of the other measures used had any obvious effect on the seizures. This patient was a mentally retarded boy aged 12 who had had previous episodes of status epilepticus and who lapsed into a severely demented state before death finally occurred, despite eventual interruption of his continuous epileptic state.
Though respiratory depression has always been regarded as a possible side-effect of diazepam, there have apparently been very few reports of this ever having occurred to a dangerous degree. Indeed, Femi-Pearse (1966) has reported the use of as much as $720 \mathrm{mg}$. daily in the treatment of tetanus without ill-effect. Gastaut et al. (1965) quote the case of a 9-month-old baby whose hemiclonic status was stopped by giving $6 \mathrm{mg}$. of diazepam intramuscularly but whose breathing then became shallow. There appeared, however, to be a slow spontaneous return later to normal respiration. In none of our cases was there any indication of respiratory depression that could be attributed to diazepam administration, though we felt it was advisable always to be prepared for such a complication.

The findings in Case 9 have been described in detail in view of the possibility that the administration of diazepam may have played some part in causing the hypotension and cerebral infarction. We have, however, given reasons why we think this unlikely. It would appear, therefore, that in none of our cases was there any evidence of depression of vital centres, despite the infusion of comparatively large amounts of diazepam.

With doses of more than $10 \mathrm{mg}$. a hypnotic effect was observed in most of our cases, and this had to be taken into account when assessing conscious levels. The development of tolerance was also a notable feature; this usually became evident within 24 hours of beginning an intravenous infusion, and appeared to be related to the total dosage given. Furthermore, when tolerance had occurred in this way it apparently could not be obviated by afterwards giving the drug intermittently. Side-effects such as mental disturbances and diuresis (Femi-Pearse, 1966) or ataxia and diplopia (Payne and Ishmael, 1963 ; Trolle, 1965) were not observed in our cases.

It is doubtful if the abnormal results of the liver function test in three of our cases could be attributed to treatment with diazepam. In the first of these (Case 5) such abnormalities could not certainly be dissociated either from previous anticonvulsant therapy or from the presumed toxic reaction to methoin in which there had been involvement of the reticuloendothelial system. Unfortunately, liver function tests had not been carried out at the time of this illness. In the other two patients (Cases 8 and 9) the raised serum aspartate aminotransferase levels could have been due to secondary effects of the status epilepticus, such as severe muscular contraction and widespread tissue hypoxia.

On the basis of the results of treatment in our small series of cases of severe convulsive status epilepticus we feel that diazepam has a useful and important part to play in the control of such states. It appears to be an effective agent, rapid in its action and apparently free from serious side-effects. It provides a useful alternative method to treatment with barbiturates and paraldehyde. Indeed, there is much to be said for regarding it as the treatment of choice in the management of all types of status epilepticus at the present time.

\section{Summary and Conclusions}

The results of the treatment with parenteral diazepam (Valium) in a series of nine cases of severe convulsive status epilepticus are reported.

In seven out of the nine patients immediate rapid control of seizures was obtained. In two of these control was only temporary, but in one of them this may have been due to inadequate dosage. Treatment by intravenous infusion was found to be the most effective method.

No serious side-effects occurred which could with certainty be attributed to treatment with diazepam.

Two patients died. In one case this was apparently due to vascular occlusion causing extensive cerebral infarction. In the second all measures used failed to control the seizures and death occurred as a result of severe brain damage. 
It is concluded that intravenous diazepam therapy has a useful and important part to play in the treatment of severe convulsive status epilepticus.

We would like to acknowledge our indebtedness to Roche Products Limited for financial assistance and to Dr. John Garrod for his interest and helpful advice. We are grateful to Dr. Denis Harriman for the necropsy findings in Case 9 and to Dr. Kenneth Exley for help with the manuscript. We should also like to thank Mrs. Grace Murray for help in preparing the illustrations and Miss Hilary Stevens for typing the manuscript.

\section{REFERENCES}

Bamberger, Ph., and Matthes, A. (1966). Z. Kinderheilk., 95, 155. Boyer, P. A., jun. (1966). Dis. nerv. Syst., 27, 35. Eidelberg, E., Neer, H. M., and Miller, M. K. (1965). Neurology (Minneap.), 15, 223.

Femi-Pearse, D. (1966). Brit. med. f., 2, 862.
Gastaut, H., Naquet, R., Poiré, R., and Tassinari, C. A. (1965). Epilepsia (Amst.), 6, 167

Goldstein, N. (1963). Dia méd. urug., 29, 4492.

Gross, H., and Kaltenbäck, E. (1963). Helv. med. Acta, 30, 660.

Hernández-Peón, R., Rojas-Ramirez, J. A., O'Flaherty, J. J., and Muzzuchelli-O'Flaherty, A. L. (1964). Int. F. Neuropharmacol., 3, 405.

Iborra, J. E. (1965). Proceedings of 8th International Conference on Neurology, Vienna, vol. IV/1, 375 .

Lombroso, C. T. (1966). Neurology (Minneap.), 16, 629.

Morillo, A. (1962). Int. 3. Neuropharmacol., 1, 353.

Naquet, R., Soulayrol, R., Dolce, G., Tassinari, C. A., Broughton, R. and Loeb, H. (1965). Electroenceph. clin. Neurophysiol., 18, 427.

Payne, R. W., and Ishmael, W. K. (1963). W est. Med., 4, 40 .

Piqué, E. R., and Henking, R. (1965). Psychiat. et Neurol. (Basel), 150, 214.

Randall, L. O., et al. (1961). Curr. ther. Res., 3, 405

Revol, M., Courjon, J., Gerin, P., and Fischer, G. (1965). Rev. neurol., $113,266$.

Schallek, W., and Kuehn, A. (1965). Med. Pharmacol. exp. (Basel), 12 ,

Zabransky, F., and Kuehn, A. (1964). Arch. int. Pharmacodyn., $149,467$.

Trolle, E. (1965). Acta neurol. scand., 41, Suppl. No. 13, 535

\title{
Intermittent Haemodialysis: Insertion and Care of the Silastic-Teflon Cannula
}

\author{
G. J. A. CLUNIE,* M.B., F.R.C.S., F.R.C.S.ED.; A. M. MARTIN, $\dagger$ M.B., M.R.C.P.ED. \\ B. NOLAN, $\ddagger$ M.B., F.R.C.S., F.R.C.S.ED.
}

Brit. med. F., 1967, 3, 88-90

The exteriorized Silastic-Teflon arteriovenous cannula introduced by Quinton, Dillard, Cole, and Scribner (1962) has simplified vessel access in patients requiring intermittent haemodialysis. Cannula complications still cause considerable discomfort and inconvenience to the patient, however, and account for much of the medical and surgical attention required. In the renal unit of the Royal Infirmary, Edinburgh, where this system of cannulation has been in regular use since October 1964, a number of modifications in the technique of insertion and aftercare of the cannulae have been made, and these are described in this report.

\section{Insertion}

All procedures were carried out in a surgical theatre. The nondominant arm was used wherever possible, the vessels cannulated being the radial artery close to the wrist and a forearm vein of adequate size. Leg cannulae were used primarily in three men whose work involved repetitive arm movements, and secondarily in one woman after loss of arm sites. The posterior tibial artery immediately proximal to the medial malleolus and the long saphenous vein at a slightly higher level provided satisfactory leg vessels (Fig. 1). Many patients requiring intermittent dialysis showed extensive atherosclerosis, and patency of and adequacy of flow through the ulnar or dorsalis pedis arteries were checked before ligation of the vessels used for cannulation.

The technique used was similar to that described by $\mathrm{Heg}$ strom, Quinton, Dillard, Cole, and Scribner (1961) and by Quinton et al. (1962). Both local and regional block anaesthesia proved satisfactory, but general anaesthesia was used in children or where multiple procedures were performed. Care was taken to avoid placing the subcutaneous loop over bone, since this

\footnotetext{
- Lecturer, Department of Surgical Science, University of Edinburgh, Edinburgh 8

† Registrar, Renal Unit, Royal Infirmary, Edinburgh 3,

₹ Consultant Surgeon, Royal Infirmary, Edinburgh 3.
}

caused early erosion of the overlying skin. Longitudinal incisions were used over the artery to allow adequate exposure, but the wounds were closed in at least two layers to bury the cannulae as deeply as possible. Transverse incisions were used for vein cannulation (Clark and Parsons, 1966), the security

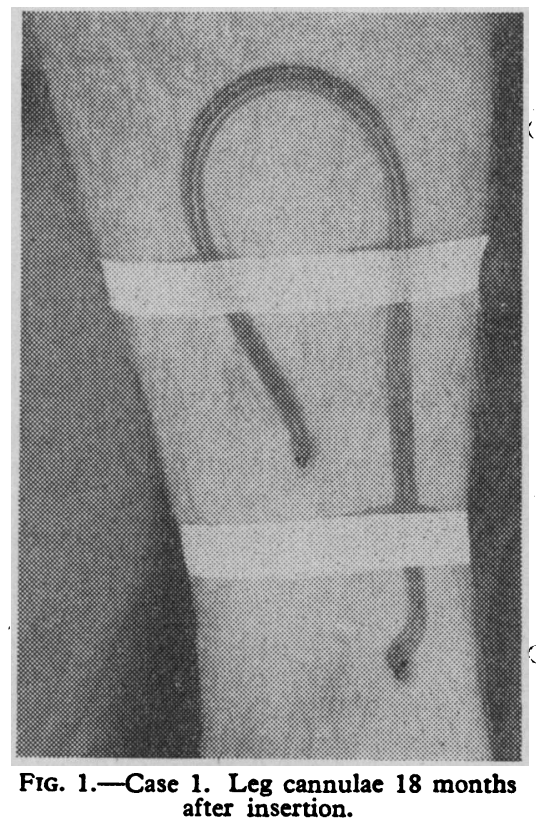

of closure and avoidance of later erosion through the wound compensating for lack of access in the more superficially placed vein. A single vertical incision proved satisfactory where artery and vein lay close together and at approximately the same level, and was particularly useful in the leg.

The Teflon tip used was the largest compatible with the original vessel diameter, and vein tips were always at least one 